\title{
Genomic and Biological Characterization of Tomato necrotic streak virus, a Novel Subgroup 2 llarvirus Infecting Tomato in Florida
}

Ismael E. Badillo-Vargas, University of Florida, North Florida Research \& Education Center (NFREC), Quincy 32351; and United States Department of Agriculture-Agricultural Research Service (USDA-ARS), Fort Pierce, FL 34945; Carlye A. Baker, Florida Department of Agriculture and Consumer Services, Division of Plant Industry, Gainesville, FL 32608; William W. Turechek, USDA-ARS, Fort Pierce; Galen Frantz and H. Charles Mellinger, Glades Crop Care, Inc., Jupiter, FL 33458; Joseph E. Funderburk, University of Florida, NFREC; and Scott Adkins, USDA-ARS, Fort Pierce

\begin{abstract}
Badillo-Vargas, I. E., Baker, C. A., Turechek, W. W., Frantz, G., Mellinger, H. C., Funderburk, J. E., and Adkins, S. 2016. Genomic and biological characterization of Tomato necrotic streak virus, a novel subgroup 2 ilarvirus infecting tomato in Florida. Plant Dis. 100:1046-1053.

Genomic and biological characterization of Tomato necrotic streak virus (TomNSV), a recently described ilarvirus infecting tomato in Florida, was completed. The full genome sequence revealed that TomNSV is a novel subgroup 2 ilarvirus that is distinct from other previously reported tomato-infecting ilarviruses: Tobacco streak virus, Parietaria mottle virus, and Tomato necrotic spot virus included in subgroup 1. In a host range experiment, TomNSV infected members of the Solanaceae and Chenopodiaceae plant families but did not infect sunflower (Helianthus annuus L.) or green bean (Phaseolus vulgaris L.). In

tomato plants, the virus moved downward to the roots from the initial point of infection and then upward from the roots to tissues of active growth such as fruit, flowers, and young leaves where symptoms were produced. Thus, young leaves, fruit, and flowers are ideal for sampling for TomNSV. The transmission rate by seed collected from infected tomato plants was determined to be $0.33 \%$. Collectively, the results of these experiments indicated that TomNSV is the causal agent of the necrotic streak disease of tomato observed in Florida since 2013.
\end{abstract}

Tomato (Solanum lycopersicum L.) is the most extensively grown vegetable crop worldwide, with fruit used raw, cooked, or processed (FAO 2015). Currently, at least 136 plant viruses in 13 families, 4 additional plant viruses unassigned to a family, one satellite virus, and seven viroids are known to infect tomato (Zitter 2014). Three members of the genus Tospovirus within the family Bunyaviridae-Tomato spotted wilt virus, Groundnut ringspot virus (GRSV), and Tomato chlorotic spot virus (TCSV) - are among the most common plant viruses infecting tomato in Florida, where they occur sympatrically (Webster et al. 2015). The begomovirus Tomato yellow leaf curl virus within the family Geminiviridae is also prevalent in Florida (Adkins et al. 2011).

In fall 2013, a previously undescribed ilarvirus was identified in tomato plants in Miami-Dade and Palm Beach Counties in south Florida during surveys for the emerging tospoviruses GRSV and TCSV (Adkins et al. 2015). Affected plants showed distinctive virus-like necrosis of leaves, petioles, and stems, and necrotic rings or spots on fruit. Sequence analysis of reverse-transcription polymerase chain reaction (RT-PCR) amplicons produced using degenerate ilarvirus primers (Agdia, Elkhart, IN) indicated that this novel virus

Corresponding author: S. Adkins; E-mail: scott.adkins@ars.usda.gov

Mention of a trademark, warranty, proprietary product or vendor does not constitute a guarantee by the U.S. Department of Agriculture and does not imply its approval to the exclusion of other products or vendors that also may be suitable.

*The $\boldsymbol{e}$-Xtra logo stands for "electronic extra" and indicates that three supplementary tables are published online.

Accepted for publication 27 January 2016.

http://dx.doi.org/10.1094/PDIS-12-15-1437-RE

This article is in the public domain and not copyrightable. It may be freely reprinted with customary crediting of the source. The American Phytopathological Society, 2016. was most closely related to subgroup 2 ilarviruses. Based on this initial characterization, the name Tomato necrotic streak virus (TomNSV) was proposed for this new virus (Adkins et al. 2015).

Members of the genus Ilarvirus (named for isometric labile ringspot virus) belong to the family Bromoviridae and can infect herbaceous and woody plants (Pallas et al. 2012). Ilarviruses have a single-stranded, positive-sense RNA genome that is divided into three linear segments designated RNA1, RNA2, and RNA3, which are encapsidated separately in quasi-icosahedral virions (Pallas et al. 2013). This genus is composed of 19 International Committee on Taxonomy of Viruses-approved virus species that infect a variety of plant hosts (Bujarski et al. 2012). Based on serology and nucleic acid sequence relationships, ilarviruses have been classified into four different subgroups (1 through 4) (Bujarski et al. 2012). All known ilarviruses encode four proteins: replicase (1a), RNA-dependent RNA polymerase (RdRp; 2a), movement protein (MP), and coat protein (CP). Subgroup 1 and 2 ilarviruses encode a fifth protein, silencing suppressor (2b) (Bujarski et al. 2012; Shimura et al. 2013). Some ilarviruses are transmitted through pollen or seed with efficiencies differing depending on the virus species, pollen source, and recipient host plant (Aparicio et al. 1999; Aramburu et al. 2010; Converse 1979; Converse and Lister 1969; George and Davidson 1963; Ghanekar and Schwenk 1974; Gilmer and Way 1963; Johnson et al. 1984; Mink 1993). Moreover, thrips have been demonstrated as vectors of ilarviruses by creating wounds during feeding that serve as entry points for virus particles present in or on infected pollen (Aramburu et al. 2010; Costa and da Costa Lima Neto 1976; Greber et al. 1991; Kaiser et al. 1982; Sdoodee and Teakle 1987, 1993).

Tobacco streak virus (TSV), the type Ilarvirus sp. and a member of subgroup 1, has long been known to infect tomato (Zitter 2014). In 1989, a new subgroup 1 ilarvirus designated Parietaria mottle virus (PMoV) was found in pellitory-of-the-wall (Parietaria officinalis L., family Urticaceae) plants and, later, in tomato plants in Italy (Aramburu et al. 2010; Caciagli et al. 1989). More recently, another distinct subgroup 1 ilarvirus, designated Tomato necrotic spot virus 
(ToNSV), was identified infecting processing tomato plants in California (Batuman et al. 2009). These two relatively recent findings, together with our initial identification of TomNSV in Florida (Adkins et al. 2015), suggest that ilarviruses may be emerging as economically important plant viruses of tomato in different geographical areas. Thus, a more comprehensive understanding of these new ilarviruses is needed for proper classification, to design sampling strategies and detection methods, and to develop control options to reduce crop losses.

In the following study, we determined the complete genome sequence of TomNSV and compared it with other ilarviruses for which sequence data are available. In addition, we established an experimental host range for TomNSV, characterized symptoms and movement in tomato plants, and examined seed transmission in tomato.

\section{Materials and Methods}

Virus source and maintenance. An isolate of TomNSV collected from tomato in Miami-Dade County, FL in 2013 (Adkins et al. 2015) was used in this study. The virus was maintained in tomato 'Florida 47' and tobacco (Nicotiana tabacum L.) 'Xanthi' plants in a greenhouse under natural lighting with a daytime high temperature of $30^{\circ} \mathrm{C}$. Graft inoculation with a mixture of symptomatic tissue from TomNSV-infected tomato and tobacco plants, including terminal shoots and leaf midribs having some internal discoloration and necrotic tissue showing external necrotic streaks alongside the veins, was used for routine passage of the virus. Thin slices of infected tissue were placed under the freshly peeled epidermis of the recipient plant, which was wrapped with grafting tape to allow healing of the graft-inoculated area. TomNSV was transmitted to the same two plant species by mechanical inoculation using symptomatic tissue homogenized in $20 \mathrm{mM}$ sodium phosphate buffer ( $\mathrm{pH}$ 7.0) containing $0.1 \%(\mathrm{wt} / \mathrm{vol})$ sodium sulfite and $1 \%(\mathrm{wt} / \mathrm{vol})$ Celite.

Sequencing and analysis of TomNSV genome. Degenerate primers were designed as part of this study from all available sequences of RNA1 and RNA2 of subgroup 2 ilarviruses to amplify and clone the genes in the corresponding RNA of TomNSV. Specific primers were designed from sequenced amplicons from the original degenerate primers when needed to obtain the full-length coding sequences for RNA1 and RNA2. Specific primers were also designed using the MP and CP gene sequences of TomNSV reported previously (Adkins et al. 2015) to amplify and clone the intergenic region (IR) from RNA3. Rapid amplification of cDNA ends was used to obtain the $5^{\prime}$ and $3^{\prime}$ untranslated regions (UTR) of the three RNA segments of TomNSV using the Gene Racer Core Kit (Invitrogen, Carlsbad, CA) following the manufacturer's instructions. Tobacco acid pyrophosphatase and poly(A) polymerase were used to remove the $5^{\prime}$ cap structure from and add a $3^{\prime}$ polyA tail to viral RNA, respectively. All primers designed and used for amplification and cloning the complete genome of TomNSV are listed in Supplementary Table S1.

Total RNA was extracted from tomato 'Florida 47' plants showing the characteristic symptoms caused by TomNSV using the RNeasy Plant Mini Kit (Qiagen, Valencia, CA). RT-PCR products of the expected sizes were cloned into the pGEM-T vector (Promega Corp., Madison, WI) using standard cloning methods. In all cases, five clones per amplicon were sequenced in both directions on an $\mathrm{ABI}$ 3730XL automated sequencer at the United States Department of Agriculture-Agricultural Research Service (USDA-ARS) U.S. Horticultural Research Laboratory DNA Sequencing Support Laboratory in Fort Pierce, FL. A consensus sequence from all forward and reverse sequences per clone was generated. Finally, all consensus sequences per RNA segment were aligned manually to obtain the complete TomNSV genome sequence. The Translate Tool from ExPASy Bioinformatics Resource Portal (http://web.expasy.org/ translate/) was used to identify five putative open reading frames (ORF). The three RNA segments composing the TomNSV genome were compared with all accepted and proposed Ilarvirus spp. for which genome sequences were available. Nucleotide and deduced amino acid sequences from all five ORF were aligned with the homologous sequences of other Ilarvirus spp. using ClustalX 2.1 and phylogenetic trees constructed by MEGA 6 using a neighbor- joining method with 1,000 bootstrap iterations. The National Center for Biotechnology Information Conserved Domain Search (http:// www.ncbi.nlm.nih.gov/Structure/cdd/wrpsb.cgi) was used to identify putative domains in the five TomNSV ORF.

Host range determination of TomNSV. Typical weed and virology indicator host species were tested as TomNSV hosts. Jimsonweed (Datura stramonium L.), American black nightshade (S. americanum Mill.), lambsquarters (Chenopodium quinoa Willd.), and tobacco (N. tabacum L. 'Xanthi,' N. tabacum 'Xanthi nc,' N. glutinosa L., and $N$. benthamiana) were grown from seed produced from virus-free source plants in a greenhouse at the USDA-ARS U.S. Horticultural Research Laboratory in Fort Pierce, FL. Commercially available seed were used for tomato 'Florida 47' and 'Lanai', pepper 'Aristotle' (Capsicum annuum L.), green bean 'Caprice' (Phaseolus vulgaris L.), and sunflower 'S672' (Helianthus annuus L.). All plants were maintained under natural lighting with a daytime high temperature of $30^{\circ} \mathrm{C}$. In all, 10 to 30 plants of each species and cultivar were mechanically inoculated at the two- to three-true-leaf stage, as described above. Alternatively, 10 to 30 plants of some species or cultivars were graft inoculated at the two- to threetrue-leaf stage, as described above. Plants were visually evaluated weekly for 3 to 4 weeks postinoculation to determine TomNSV infection status. RNA was extracted from upper, noninoculated leaves of pepper, green bean, and sunflower plants and tested by RT-PCR for TomNSV. Firststrand cDNA was synthesized by Moloney murine leukemia virus reverse transcriptase (Promega Corp.) at $45^{\circ} \mathrm{C}$ for $45 \mathrm{~min}$ with standard methods (Sambrook and Russell 2001) using a random hexanucleotide primer mix (Roche, Indianapolis, IN). This was followed by 30 cycles of PCR amplification with Taq polymerase (Promega Corp.) at $94^{\circ} \mathrm{C}$ for $30 \mathrm{~s}, 60^{\circ} \mathrm{C}$ for $30 \mathrm{~s}$, and $72^{\circ} \mathrm{C}$ for $45 \mathrm{~s}$ using degTomNSV RNA3_MPv $\left(5^{\prime}\right.$-CCCAC TACCTAMTYAACTGTGGAT-3') and degTomNSV RNA3_MPvc (5'-CCCAAATMAGGGTATCCATCCCAC-3') primers located in the MP gene.

Detection of TomNSV from field samples. In total, 210 plant samples with virus-like symptoms similar to those of TomNSV were collected from six counties in south Florida (Collier, Hendry, Lee, Manatee, Palm Beach, and Miami-Dade) from fall 2013 through fall 2015. Samples were predominantly collected from tomato $(n=152)$ but also included pepper $(n=13)$, scarlet eggplant (S. aethiopicum L.; $n=6$ ), eggplant (S. melongena L.; $n=1$ ), tomatillo (Physalis philadelphica Lam.; $n=5$ ), and sweet potato (Ipomoea batatas (L.) Lam.; $n=6$ ). Common weeds in Palm Beach and Miami-Dade County fields from which the original TomNSV isolates were collected in fall 2013 were collected and included American black nightshade $(n=4)$, creeping-oxeye (Wedelia spp.; $n=5$ ), pigweed (Amaranthus spp.; $n=3$ ), ragweed (Ambrosia spp.; $n=3$ ), morning glory (Ipomoea spp.; $n=3$ ), false daisy (Eclipta prostrata L.; $n=3$ ), Caesar weed (Urena lobata L.; $n=3$ ), and Balsam-apple (Momordica charantia L.; $n=3$ ). RNA was extracted and tested by RTPCR with degTomNSV RNA3_MPv and degTomNSV RNA3_MPvc primers, as described above.

Distribution and movement of TomNSV in tomato plants. Two experiments examined the distribution and movement of TomNSV in tomato 'Florida 47' plants that were graft inoculated at a single location about $1 \mathrm{~cm}$ above the soil line. In the first experiment, six plants were graft inoculated and maintained for 3 weeks. Each plant was sectioned into fruit, flowers, young leaves, mature leaves, middle stem (above graft), lower stem (below graft), and roots at the onset of symptom development. In the second experiment, six plants were graft inoculated and one plant was sectioned (as described above) each week during a 6-week period. For this second experiment, two plants were sectioned before the onset of symptoms (weeks 1 and 2 ), one plant was sectioned at the onset of symptoms (week 3), and three plants were sectioned after symptom development (weeks 4, 5, and 6). Total RNA extracted from each section of each plant was tested by RT-PCR using primers for TomNSV RNA1 (TomNSV RNA1_Iv [5'-ACGGAGTGGCAGGTTGTGGA-3'] and TomNSV RNA1_Ivc [5'-ATGTCATCTGGATCATCAGCATAGA-3']), RNA2 (TomNSV RNA2_Cv [5'-AGGGGATCGTGATGCAGTCA-3'] and TomNSV RNA2_Cvc [5'-GGTATGCGCATAACTCTGCA-3']), and RNA3 (degTomNSV RNA3_MPv and degTomNSV RNA3_MPvc). 
Seed transmission of TomNSV. In total, 1,336 seeds collected from tomato fruit produced on graft-inoculated TomNSV-infected 'Florida 47' plants were sown in Styrofoam transplant trays ( 8 by 16 cells) in Fafard 4P growing medium (Sun Gro Horticulture, Agawam, MA) to determine whether TomNSV could be transmitted via seed. Another 72 commercial 'Florida 47' seeds were similarly sown as noninfected controls. After 10 weeks, 24 seedlings were randomly selected from the 909 seedlings that grew from the 1,336 seeds collected from tomato fruit from infected plants, transplanted into 11.4liter pots, and grown to maturity to monitor symptom development and flower and tomato fruit production for a 2 -month period. Similarly, four seedlings were randomly selected from the 65 seedlings that grew from the 72 commercial seeds, transplanted into 11.4-liter pots, and grown to maturity for comparison. Leaf tissue (nondestructive sampling) from these transplanted seedlings was used to test for the presence of TomNSV by RT-PCR with degTomNSV RNA3_MPv and degTomNSV RNA3_MPvc primers, as described above. A $0.5-\mathrm{cm}$ piece of stem from each of the seedlings remaining in transplant trays was collected (destructive sampling), pooled in groups of eight, and tested for TomNSV in the same manner. Seedlings from pools that tested positive for TomNSV were then assayed individually to determine the exact number of infected seedlings. Leaf tissue from individual tomato seedlings shown by RT-PCR to be infected with TomNSV was subsequently used to graft inoculate tomato 'Lanai' plants, as described above, to determine whether the virus was infectious. Inoculated plants were observed daily for development of symptoms and tested by RT-PCR with degTomNSV RNA3_MPv and degTomNSV RNA3_MPvc primers, as described above, to confirm the presence of TomNSV.

In September 2015, a single tomato 'Camelia' plant was observed with typical TomNSV symptoms in Palm Beach County. The remaining 53 seeds from the same lot were obtained from the grower and tested individually for the presence of TomNSV. The clay coating of these pelleted seeds was removed by gently crushing the coating with needle-nose pliers while leaving the tomato seed intact. Seed were ground individually in $1.5-\mathrm{ml}$ tubes with plastic pestles and RNA was extracted using the RNeasy Plant Mini Kit (Qiagen). RT-PCR testing with degTomNSV RNA3_MPv and degTomNSV RNA3_MPvc primers was used for virus detection, and an endogenous gene from tomato (clathrin adaptor complexes [CAC]) was used as a control for nucleic acid extraction from seed using previously described primers (Expósito-Rodríguez et al. 2008).

\section{Results}

Genome organization and sequence analysis of TomNSV. The complete genome of TomNSV was found to be 8,621 nucleotides (nt), with RNA1, RNA2, and RNA3 being 3,378, 3,024, and 2,219 nt in length, respectively (Fig. 1; Supplementary Table S2; accession numbers KT779204, KT779205, and KT779206, respectively).

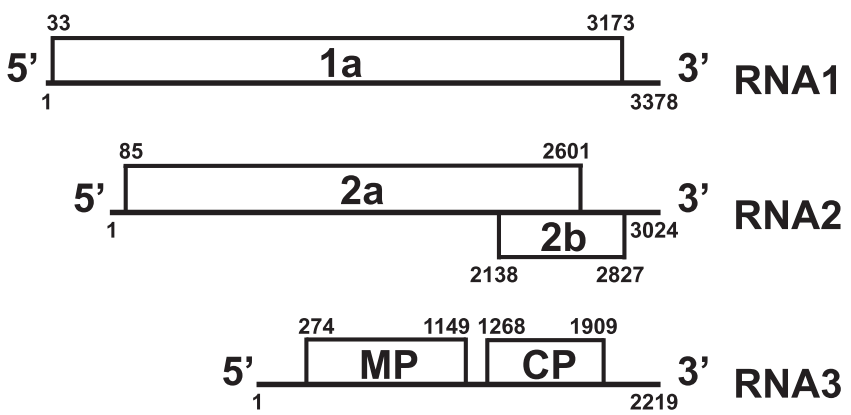

Fig. 1. Genome organization of Tomato necrotic streak virus. Three genomic RNA segments are shown as solid lines, with the nucleotides indicated at $5^{\prime}$ and $3^{\prime}$ termini. Predicted open reading frames are shown as boxes containing protein names and nucleotides (shown above or below) indicating start and stop codons. RNA1 encodes 1a (replicase), RNA2 encodes 2a (RNA-dependent RNA polymerase) and $2 b$ (silencing suppressor), and RNA3 encodes movement protein (MP) and coat protein (CP).
RNA1 encoded the 1a gene (3,141 nt) and protein (1,046 amino acids [aa]). In contrast, RNA2 and RNA3 each encoded two genes. RNA2 encoded the $2 \mathrm{a}$ gene $(2,517 \mathrm{nt})$ and protein $(838 \mathrm{aa})$ and the $2 \mathrm{~b}$ gene $(690 \mathrm{nt})$ and protein $(229 \mathrm{aa})$. The latter is predicted to be expressed from a subgenomic RNA designated RNA4a (Shimura et al. 2013). The $2 \mathrm{a}$ and $2 \mathrm{~b}$ genes overlapped by $464 \mathrm{nt}$. RNA3 encoded the MP gene (876 nt) and protein (291 aa) and the CP gene (642 nt) and protein (213 aa), the latter being expressed from a subgenomic RNA designated RNA4 (Pallas et al. 2013). The IR between the MP and $\mathrm{CP}$ genes in the RNA3 was found to be $118 \mathrm{nt}$, with a GC content of $51 \%$. The $5^{\prime}$ UTR of RNA1, RNA2, and RNA3 were 32,84 , and $273 \mathrm{nt}$ in length, respectively. Although variable in length, the $5^{\prime}$ UTR of the three RNA segments shared four nucleotides (TATT) at varying distances upstream from the start codon of the 1a, 2a, and MP genes. Also variable in length, the $3^{\prime}$ UTR of RNA1, RNA2, and RNA3 were 205, 197, and $310 \mathrm{nt}$, respectively. However, the $3^{\prime}$ UTR shared $>96 \%$ nucleotide identity over the $3^{\prime}$-most $197 \mathrm{nt}$. All clones of each individual UTR were consistent in length, ensuring that the full-length sequence was obtained.

Neighbor-joining phylogenetic trees constructed using the nucleotide sequences from the five genes of all ilarviruses for which sequence data were available clearly supported the placement of TomNSV in subgroup 2 (Fig. 2). Identical tree topologies for all subgroup 2 ilarviruses were obtained when using the deduced amino acid sequences from the five genes (data not shown). Sequence analysis indicated that four of the TomNSV genes (1a, 2a, $\mathrm{MP}$, and $\mathrm{CP}$ ) were most similar to but distinct from the corresponding genes of Tulare apple mosaic virus (TAMV) in the subgroup 2 ilarviruses (Fig. 2A, B, D, and E). The TomNSV 1a, 2a, MP, and CP genes were $82,84,79$, and $83 \%$ identical at the nucleotide level and $80,77,81$, and $83 \%$ identical at the amino acid level, respectively, to those of TAMV. In contrast, the $2 \mathrm{~b}$ gene was most similar to that of Citrus leaf rugose virus (CLRV), another subgroup 2 ilarvirus (Fig. 2C). The TomNSV 2b gene was $78 \%$ identical to CLRV but only $76 \%$ identical to TAMV at the nucleotide level (Supplementary Table S3). Similarly, the TomNSV 2 b protein was $70 \%$ identical to CLRV but only $64 \%$ identical to TAMV at the amino acid level. The TomNSV $2 \mathrm{~b}$ gene and protein were more distantly related to other subgroup 2 ilarviruses. Using the nucleotide and deduced amino acid sequences of TomNSV genes, we identified predicted functional domains and amino acids or motifs, respectively, which matched the known role of the viral proteins in the replication cycle of other well-characterized ilarviruses, including species within subgroup 2 (Pallas et al. 2013). For example, the 1a gene had methyltransferase and helicase domains, and the $2 \mathrm{a}$ gene had an RdRp domain.

Experimental host range determination and symptoms caused by TomNSV. An experimental host range for TomNSV was determined by mechanical and graft inoculation of 10 plant species, some including multiple cultivars, representing four plant families (Solanaceae, Chenopodiaceae, Asteraceae, and Fabaceae; Table 1). No differences were observed in the symptoms or incidence of infection based on the inoculation method (mechanical or graft); therefore, data from both methods were pooled for analysis and presentation (Table 1; Fig. 3). Upper, noninoculated leaves of 78 and $57 \%$ of N. tabacum 'Xanthi' (Fig. 3A) and N. tabacum 'Xanthi nc' (Fig. 3B) plants, respectively, developed the necrotic streak symptom characteristic of TomNSV infection. $N$. benthamiana developed necrotic lesions on the leaves of $20 \%$ of the plants, whereas $N$. glutinosa developed the necrotic streak symptom on upper, noninoculated leaves of $29 \%$ of the plants, as a consequence of TomNSV infection. More importantly, $74 \%$ of tomato 'Florida 47' plants (Fig. 3C) and $61 \%$ of tomato 'Lanai' plants became infected by TomNSV and developed the typical necrotic streaks alongside the veins. We observed that, during the early days after infection, most of the flowers present at the time of inoculation were aborted. However, flowers that developed after the plant was already infected produced small fruit that did not display any visible symptoms. In contrast, fruit that were already developing on tomato plants before inoculation with TomNSV developed a symptom 

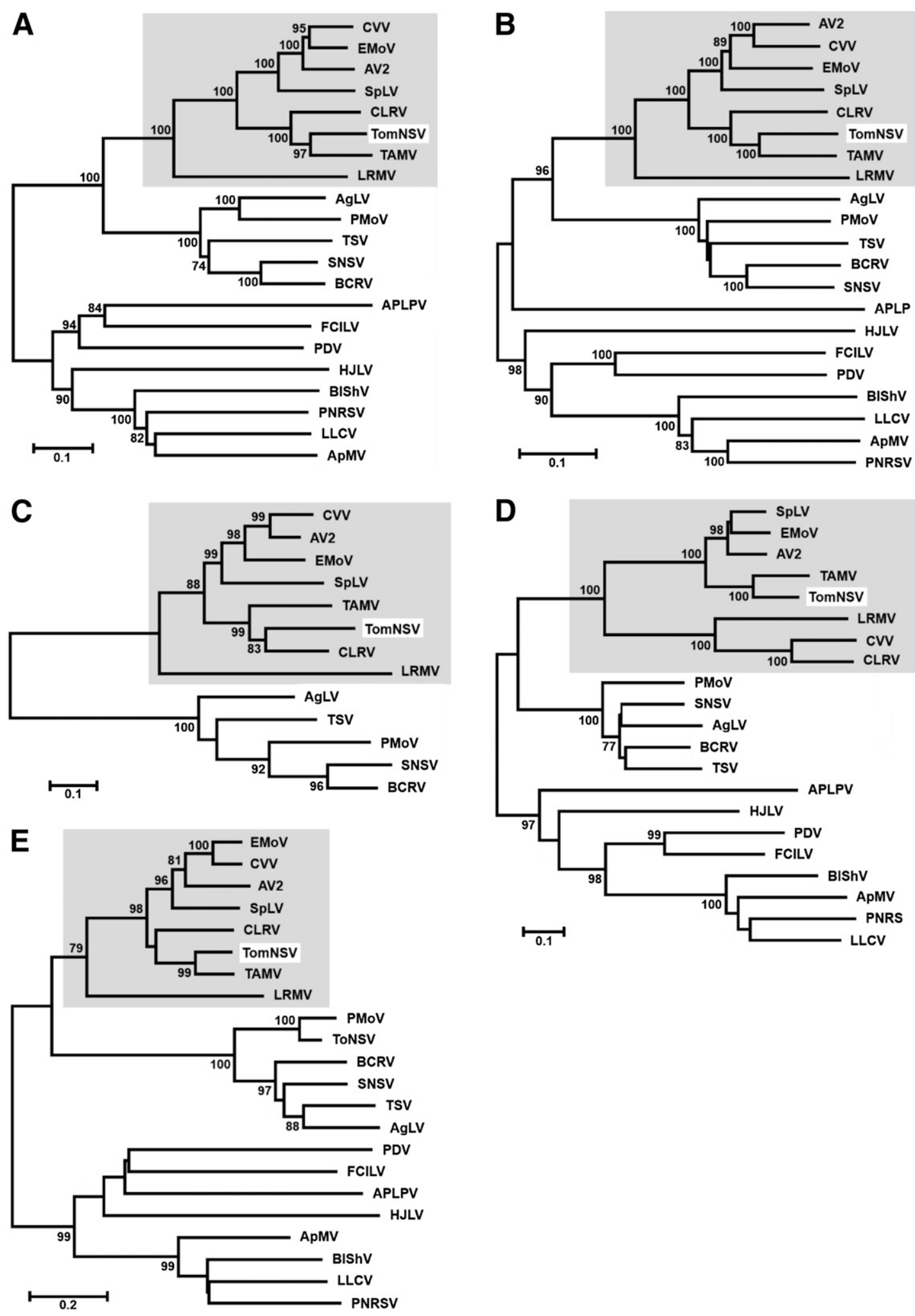

Fig. 2. Phylogenetic relationship of Tomato necrotic streak virus (TomNSV) with accepted and proposed members of the genus llarvirus. Phylogenetic trees constructed using the neighborjoining method with all available nucleotide sequences of A, 1a (replicase); B, 2a (RNA-dependent RNA polymerase); C, 2b (silencing suppressor); D, movement protein; and E, coat protein genes. TomNSV is indicated with a white box within subgroup 2 ilanviruses, indicated with a gray box. Bootstrap values (1,000 iterations) $\geq 70 \%$ are shown. Subgroup 1: Ageratum latent virus (AgLV; NC_022127.1, NC_022128.1, and NC_022129.1), Blackberry chlorotic ringspot virus (BCRV; NC_011553.1, NC_011554.1, and GQ325716.1), Parietaria mottle virus (PMoV; FJ858202.1, NC_005849.1, and NC_005854.1), Strawberry necrotic shock virus (SNSV; DQ318818.3, NC_008707.1, and NC_008706.1), Tomato necrotic spot virus (ToNSV; FJ236810.1), and Tobacco streak virus (TSV; KM504246.1, U75538.1, and NC 003845.1). Subgroup 2: Asparagus virus 2 (AV2; EU919666.1, NC 011809.1, and NC 011807.1), Citrus leaf rugose virus (CLRV; U23715.1, NC_003547.1, and JX256249.1), Citrus variegation virus (CVV; NC_009537.1, NC_009538.1, and NC_009536.1), Elm mottle virus (EMoV; U57047.1, NC_003568.1, and U85399.1), Lilac ring mottle virus (LRMV; EU919668.1, EU919669.1, and U17391.1), Spinach latent virus (SpLV; U93192.1, NC_003809.1, and NC_003810.1), Tulare apple mosaic virus (TAMV; NC_003833.1, NC_003834.1, and AF226162.1), and TomNSV (KT779204, KT779205, and KT779206). Subgroup 3: Apple mosaic virus (ApMV; NC_003464.1, NC_003465.1, and NC_003480.1), Blueberry shock virus (BIShV; KF031037.1, NC_022251.1, and NC_022252.1), and Prunus necrotic ringspot virus (PNRSV; NC_004362.1, NC_004363.1, and NC_004364.1). Subgroup 4: Fragaria chiloensis latent virus (FCILV; NC_006566.1, NC_006567.1, and NC_006568.1) and Prune dwarf virus (PDV; NC_008039.1, NC_008037.1, and NC_008038.1). No subgroup determined: American plum line pattern virus (APLPV; NC_003451.1, NC_003452.1, and NC_003453.1), Humulus japonicas latent virus (HJLV; AY500236.1, NC_006065.1, and AY500238.1), and Lilac leaf chlorosis virus (LLCV; HE572565.1, NC_025478.1, and NC_025481.1). 
commonly referred to by growers as "zippering" (because of its resemblance to a closed zipper) that was visible before (Fig. 3D) and after (Fig. 3E) ripening. No infection was observed or detected in the remaining solanaceous species tested: pepper, Jimsonweed, and American black nightshade. Lambsquarters in the family
Chenopodiaceae, a typical virus indicator host, was the only other plant species in which TomNSV infection was observed (Table 1). Chlorotic and necrotic lesions and streaks alongside the veins (Fig. 3F) were observed on $77 \%$ of inoculated lambsquarters plants Growing points of infected lambsquarters plants consistently

Table 1. Plants inoculated with Tomato necrotic streak virus to establish experimental host range

\begin{tabular}{|c|c|c|c|}
\hline Family, species, and cultivar & Common name & Symptomatic plants & Symptoms $^{\mathbf{a}}$ \\
\hline \multicolumn{4}{|l|}{$\begin{array}{l}\text { Asteraceae } \\
\text {. }\end{array}$} \\
\hline Helianthus annuus & Sunflower & $0 / 40$ & $-1-$ \\
\hline \multicolumn{4}{|l|}{ Fabaceae } \\
\hline Phaseolus vulgaris 'Caprice' & Green bean & $0 / 10$ & $-1-$ \\
\hline \multicolumn{4}{|l|}{ Chenopodiaceae } \\
\hline Chenopodium quinoa & Lambsquarters & $44 / 57$ & $\mathrm{CL}, \mathrm{NL} / \mathrm{NS}, \mathrm{B}, \mathrm{SC}$ \\
\hline \multicolumn{4}{|l|}{ Solanaceae } \\
\hline Capsicum anпиит 'Aristotle' & Pepper & $0 / 40$ & $-1-$ \\
\hline Datura stramonium & Jimsonweed & $0 / 10$ & $-1-$ \\
\hline Nicotiana benthamiana & & $4 / 20$ & $\mathrm{NL} / \mathrm{NL}$ \\
\hline N. glutinosa & & $4 / 14$ & $-/ \mathrm{NS}$ \\
\hline N. tabacum 'Xanthi' & Tobacco & $28 / 36$ & $-/ \mathrm{NS}$ \\
\hline N. tabacum 'Xanthi nc' & Tobacco & $30 / 53$ & $-/ \mathrm{NS}$ \\
\hline Solanum americanum & American black nightshade & $0 / 20$ & $-1-$ \\
\hline S. lycopersicum 'Florida 47' & Tomato & $73 / 98$ & $-/ \mathrm{NS}$ \\
\hline S. lycopersicum 'Lanai' & Tomato & $23 / 38$ & $-/ \mathrm{NS}$ \\
\hline
\end{tabular}

a Symptoms on inoculated and upper, noninoculated leaves indicated to left and right of slash, respectively: $-=$ no symptoms, $\mathrm{B}=$ "brittle," CL = chlorotic lesion, $\mathrm{NL}=$ necrotic lesion, $\mathrm{NS}=$ necrotic streaks alongside veins, and $\mathrm{SC}=$ stem tip curvature.
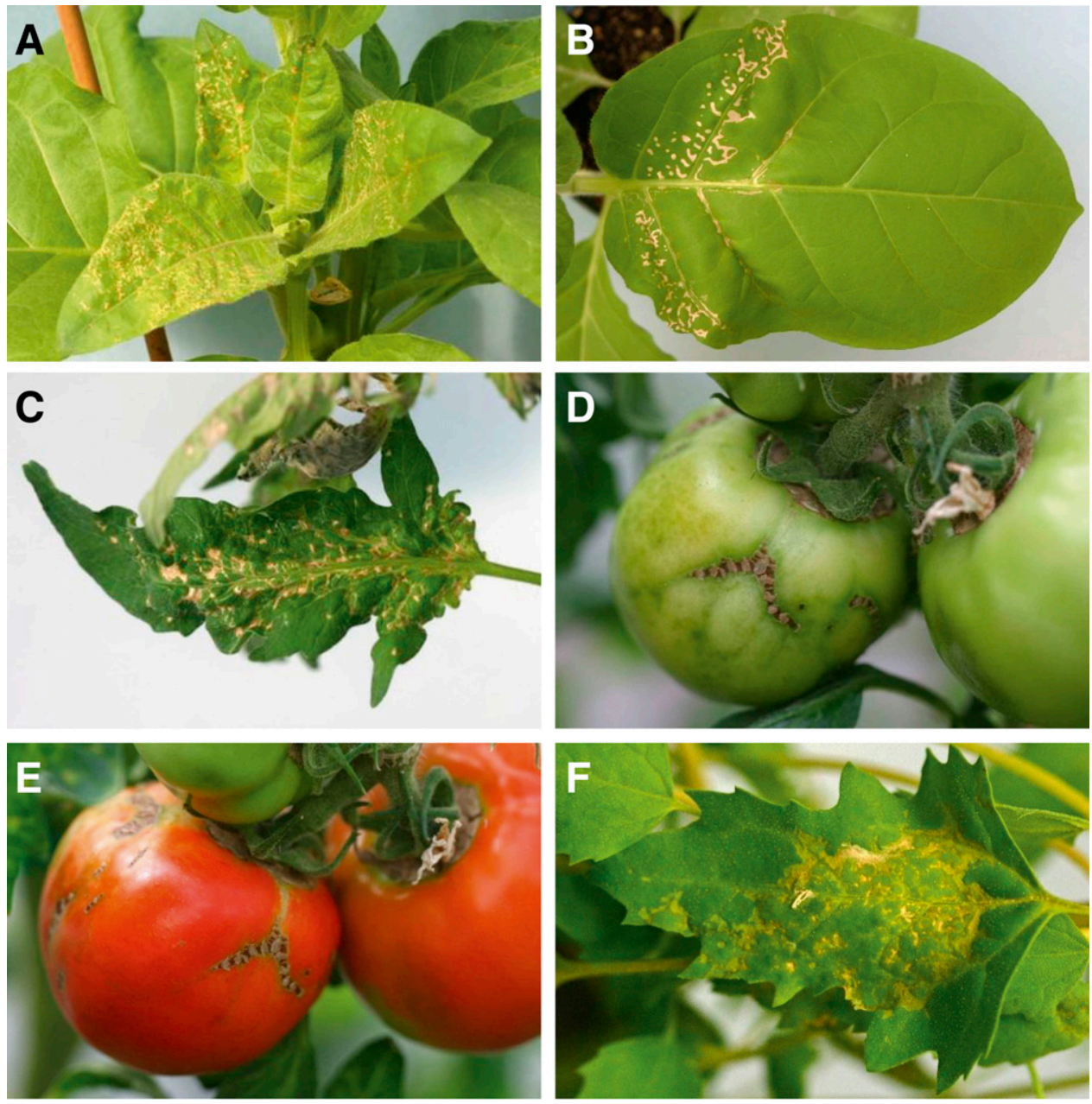

Fig. 3. Symptoms caused by Tomato necrotic streak virus (TomNSV) infection. A, Tobacco Nicotiana tabacum 'Xanthi' and B, 'Xanthi nc' inoculated with TomNSV developed necrotic streaks alongside the veins of upper, noninoculated leaves. C, Tomato 'Florida 47 ' leaflet showing typical necrotic streaks and D, fruit with zippering symptoms visible before and $\mathbf{E}$, after ripening following TomNSV inoculation. F, Necrotic veins on lambsquarters leaf inoculated with TomNSV. 
curved down, and flowers forming at the time of TomNSV infection never matured. Leaves and petioles of TomNSV-infected lambsquarters plants became "brittle" and broke easily, causing the plants to defoliate prematurely and, ultimately, die 4 to 7 days postinoculation. No infection was observed or detected in the single Asteraceae (sunflower) or Fabaceae (green bean) species tested (Table 1).

Detection of TomNSV from field samples. Of the 152 tomato plants tested, 66, 38, and 1\% were positive for TomNSV in 2013, 2014, and 2015, respectively. All TomNSV-infected tomato samples were collected in Palm Beach or Miami-Dade County, in the same or adjacent fields from which the original TomNSV isolates were collected in fall 2013. No other crop or weed plants were found naturally infected with TomNSV, even those collected in fields where TomNSV-infected tomato plants were present simultaneously.

Distribution and movement of TomNSV in tomato plants. We individually sectioned six tomato 'Florida 47' plants 3 weeks following graft inoculation with TomNSV at a single location to determine the distribution of this virus within infected tomato plants. RT-PCR using primers to detect the three RNA segments of the virus showed that all three TomNSV genomic RNA segments were present in fruit, flowers, young leaves, middle stem (above graft), lower stem (below graft), and roots. In contrast, none of the three RNA segments were present in mature leaves at this time.

Results of a second experiment to analyze movement of TomNSV in tomato 'Florida 47' plants that were graft inoculated at a single location about $1 \mathrm{~cm}$ above the soil line are shown in Figure 4. No TomNSV was detected in any of the sections tested 1 week after inoculation. TomNSV was detected in the small tomato fruit, lower stem (below graft), and roots 2 weeks after inoculation, although symptoms were not yet present. By the third week after inoculation, at the onset of symptom development, the virus was detected in all sections except for mature leaves. This pattern of virus movement within infected tomato 'Florida 47' plants remained the same at 4,5 , and 6 weeks after inoculation whereas the necrotic streak symptoms continued to progress until the end of the experiment at 6 weeks.

Seed transmission of TomNSV. In all, 3 of 909 seedlings from seed of fruit produced by TomNSV-infected tomato 'Florida 47' were positive for TomNSV when tested by RT-PCR. This represents a $0.33 \%$ seed transmission rate. None of these seedlings showed any visible symptoms before or at the time of sample collection but two developed very slight necrosis and chlorosis when stored overnight at $4^{\circ} \mathrm{C}$ (Fig. 5A). Of the 3 seedlings that were positive for TomNSV, 1 was among the 24 seedlings that were transplanted and grown to maturity for 2 months. This tomato plant was stunted, had severe leaf distortion, aborted the first flowers, and eventually produced very small fruit (Fig. 5B). None of the 65 commercial tomato 'Florida 47 ' seedlings were positive for TomNSV and all exhibited normal growth and fruiting in comparison with the TomNSV-infected plant (Fig. 5B). Tomato 'Lanai' plants graft inoculated with tissue from the three TomNSVpositive seedlings developed necrotic streaks 5 to 6 days after inoculation (Fig. 5C and D).

None of the remaining 53 commercial tomato 'Camelia' seeds from the same seed lot from which the single 2015 TomNSVpositive tomato plant originated were positive for TomNSV when tested by RT-PCR. However, all 53 seeds were positive for the tomato endogenous CAC gene used as an internal control, demonstrating that RNA extraction from each seed was successful.

\section{Discussion}

In this study, we report the complete genome sequence of a newly discovered ilarvirus infecting tomato in Florida, for which the name

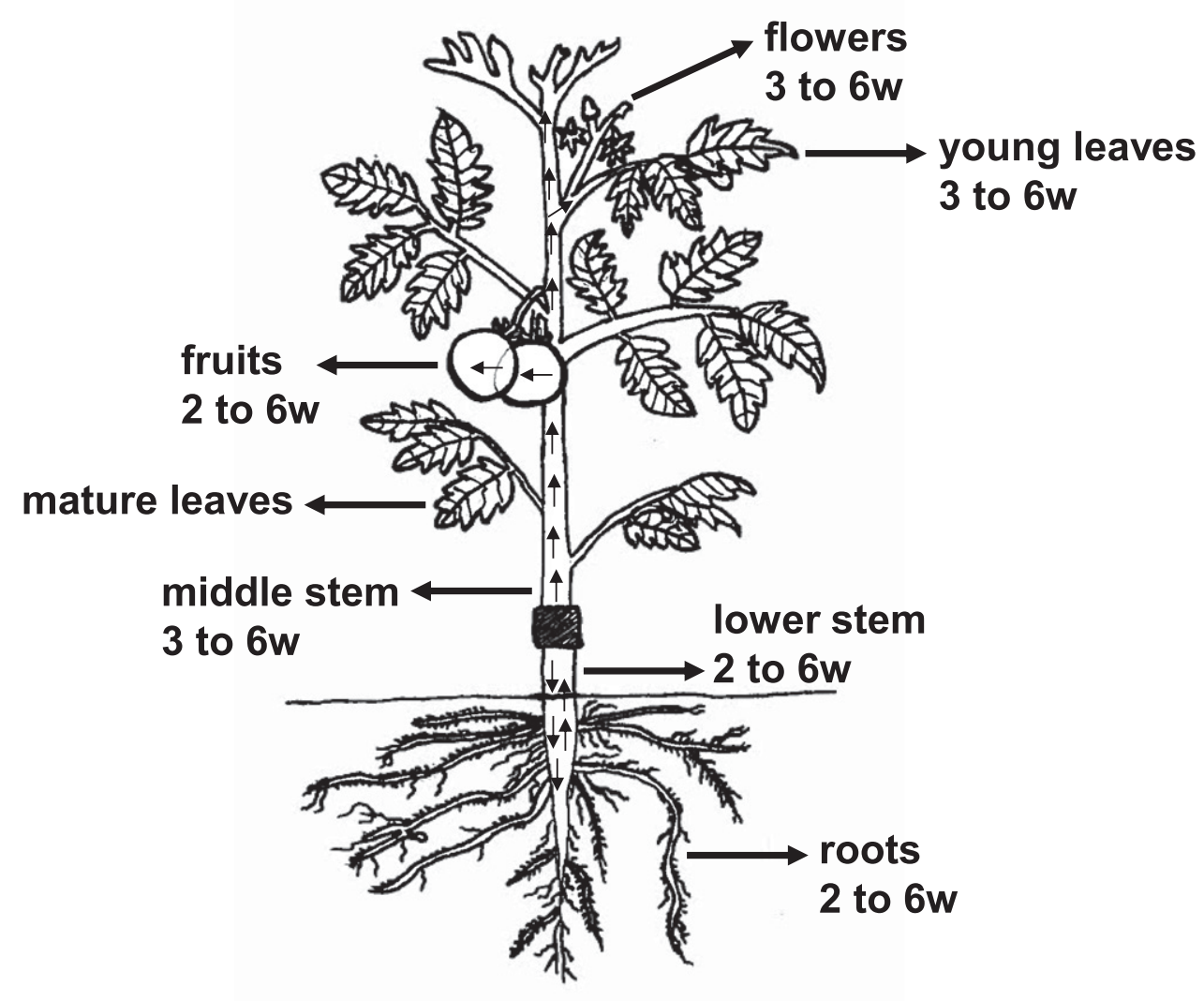

Fig. 4. Distribution and movement of Tomato necrotic streak virus (TomNSV) in graft-inoculated tomato plants. Tomato 'Florida 47' plants were graft inoculated at a single location (indicated with a black square) about $1 \mathrm{~cm}$ above the soil line. One tomato plant per week was dissected into fruit, flowers, young leaves, mature leaves, middle stem (above the inoculation point), lower stem (below the inoculation point), and roots for a 6-week period. Numbers below the plant tissue names indicate the weeks (w) at which the three viral RNA segments were detected in these tissues. Small black arrows depict TomNSV movement within a tomato plant. 
TomNSV has been proposed. TomNSV has a genome organization typical of members of the genus Ilarvirus (Fig. 1) and, specifically, subgroup 2 ilarviruses, as shown by phylogenetic analyses of the five viral genes (Fig. 2). This is in contrast to the other ilarviruses reported to infect tomato (TSV, PMoV, and ToNSV), which are all members of subgroup 1 (Zitter 2014). Sequences of the TomNSV 1a, 2a, MP, and CP genes showed the highest nucleotide identity to TAMV, whereas the $2 \mathrm{~b}$ gene showed highest nucleotide identity to CLRV. The two closest relatives to TomNSV within subgroup 2 ilarviruses, TAMV and CLRV, have not been reported to infect tomato. Although there is currently no specified level of sequence similarity to distinguish Ilarvirus spp. or subgroups, all sequence results in this study supported placement of TomNSV in subgroup 2 of the genus Ilarvirus.

In a host range experiment, TomNSV infected four Solanaceae species (tomato and three tobacco species) and one Chenopodiaceae species (lambsquarters) (Table 1), which displayed the necrotic streak symptom characteristic of this virus (Fig. 3). We were able to transmit and maintain TomNSV by both mechanical and graft inoculation, and these two inoculation methods did not result in any difference in the symptoms observed. However, because TomNSV transmission in the field is likely through thrips, the natural host range for TomNSV may be broader than our experimental results suggest. Anecdotal evidence suggests that high temperatures make mechanical inoculation less successful. A reduced titer of subgroup 2 TAMV in maturing leaves of apple seedlings at high temperatures has been reported previously (Garnsey 1964). Given the warm climate of Florida, this might explain, at least in part, why none of the three genomic RNA segments of TomNSV were present in mature tomato leaves at any of the time points used in our evaluations. The distribution and movement of TomNSV within plants (Fig. 4) was similar to that of other well-characterized plant viruses. From the initial infection site, the virus moved downward to the roots and then upward from the roots to tissues of active growth such as fruit, flowers, and young leaves, where symptoms were produced (Samuel 1934). Our results indicated that young leaves, fruit, and flowers are ideal for sampling for TomNSV.

We observed a low rate of TomNSV transmission in seed collected from fruit produced by TomNSV-infected tomato 'Florida 47' plants. Graft inoculation with the TomNSV-infected seedlings indicated that the seed-transmitted virus was infectious. Varying rates of seed transmission were reported for other ilarviruses, sometimes within a single virus species. For example, Ageratum latent virus was transmitted by seed in Ageratum houstonianum at rates of 0 to $18 \%$ (Greber et al. 1991; Klose 1997; Sdoodee and Teakle 1988; Sharman and Thomas 2013). Although a low rate of seed transmission was observed for TomNSV, only a few plants infected in this manner are necessary for field level symptoms to become evident. Additional support for a low rate of seed transmission was found by testing seed from the commercial tomato seed lot from which the single 2015 TomNSVinfected tomato 'Camelia' plant originated. No TomNSV was detected in the 53 seeds tested, although we acknowledge that this is too few seed to detect the measured $0.33 \%$ transmission rate. It is important to note that we did not treat the tomato seed used in our seed transmission assay with any common sanitizing agents such as trisodium phosphate. Thus, the seed transmission observed could have resulted from either virus contamination of the seed or from actual infection of the embryo. Additional experiments to clarify the exact location of TomNSV in tomato seed are needed to distinguish between these two possibilities.

TomNSV has been present at a relatively low incidence in tomato in south Florida since at least fall 2013. Due to the similarity of TomNSV fruit symptoms with those induced by tospoviruses established in south Florida (Webster et al. 2015), it is likely that symptoms associated with the initial introduction and early epidemics of TomNSV were attributed to other viruses. The low level of TomNSV transmission by seed demonstrated experimentally, and the lack of detection of TomNSV in a commercial tomato seed
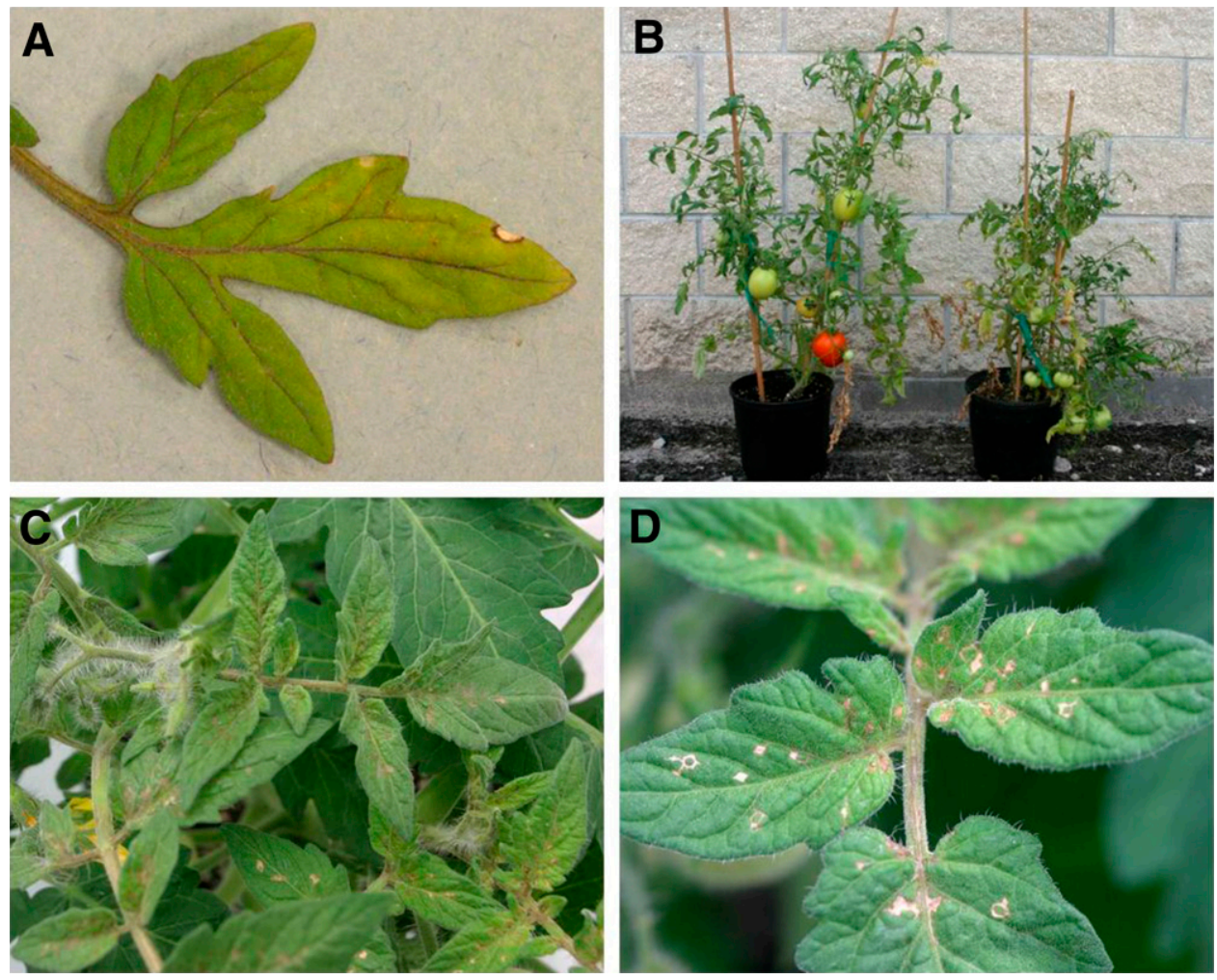

Fig. 5. Seed transmission of Tomato necrotic streak virus (TomNSV). A, Leaf of tomato seedling that tested positive for TomNSV by reverse-transcription polymerase chain reaction displaying slight necrosis and chlorosis after refrigeration. B, Mature tomato plant from infected seed (right) was stunted, had severe malformation of leaves and leaflets, and was delayed in fruit set compared with a virus-free tomato plant from the commercial 'Florida 47' seed control group (left). C and D, Characteristic necrotic streak symptoms developed on tomato 'Lanai' plants graft inoculated with tissue from TomNSV-infected seedling grown from seed of fruit of TomNSV-infected 'Florida 47' tomato. 
lot from which the single 2015 finding of TomNSV in Florida was grown, suggested that seed may not be the most important source of TomNSV. Further surveys for potential reservoir hosts in south Florida and testing of locally important thrips species as potential vectors are warranted.

\section{Acknowledgments}

We thank C. Vanderspool, R. Lewis, J. Skaryd, S. Hanson, and R. Noel for their excellent technical assistance; and numerous scouts and growers for help with sample collection. This research was supported, in part, by Florida Specialty Crop Block Grant 21721.

\section{Literature Cited}

Adkins, S., Baker, C. A., Badillo-Vargas, I. E., Frantz, G., Mellinger, H. C., Roe, N., and Funderburk, J. E. 2015. Necrotic streak disease of tomato in Florida caused by a new ilarvirus species related to Tulare apple mosaic virus. New Dis. Rep. 31:16

Adkins, S., Webster, C. G., Kousik, C. S., Webb, S. E., Roberts, P. D., Stansly, P. A., and Turechek, W. W. 2011. Ecology and management of whiteflytransmitted viruses of vegetable crops in Florida. Virus Res. 159:110-114.

Aparicio, F., Sanchez-Pina, M. A., Sanchez-Navarro, J. A., and Pallas, V. 1999. Location of Prunus necrotic ringspot virus within pollen grains from infected nectarine trees: Evidence from RT-PCR, dot-blot, and in situ hybridization. Eur. J. Plant Pathol. 105:623-627.

Aramburu, J., Galipienso, L., Aparicio, F., Soler, S., and López, C. 2010. Mode of transmission of Parietaria mottle virus. J. Plant Pathol. 92:679-684.

Batuman, O., Miyao, G., Kuo, Y.-W., Chen, L.-F., Davis, R. M., and Gilbertson, R. L. 2009. An outbreak of a necrosis disease of tomato in California in 2008 was caused by a new ilarvirus species related to Parietaria mottle virus. Plant Dis. 93:546.

Bujarski, J., Figlerowicz, M., Gallitelli, D., Roossinck, M. J., and Scott, S. W. 2012. Family Bromoviridae. Pages 965-976 in: Virus Taxonomy: Classification and Nomenclature of Viruses: Ninth Report of the International Committee on Taxonomy of Viruses. A. M. Q. King, M. J. Adams, E. B. Carstens, and E. J. Lefkowitz, eds. Elsevier Academic Press, San Diego, CA.

Caciagli, P., Boccardo, G., and Lovisolo, O. 1989. Parietaria mottle virus, a possible new ilarvirus from Parietaria officinalis (Urticaceae). Plant Pathol. 38:577-584.

Converse, R. H. 1979. Transmission of Tobacco streak virus in Rubus. Acta Hortic. 95:53-61.

Converse, R. H., and Lister, R. M. 1969. The occurrence and some properties of Black raspberry latent virus. Phytopathology 59:325-333.

Costa, A. S., and da Costa Lima Neto, V. 1976. Transmissao do virus da necrose branca do fumo por Frankliniella sp. Congr. Soc. Bras. Fitopatol. 9:1.

Expósito-Rodríguez, M., Borges, A. A., Borges-Pérez, A., and Pérez, J. A. 2008. Selection of internal control genes for quantitative real-time RT-PCR studies during tomato development process. BMC Plant Biol. 8:131.

FAO. 2015. FAOSTAT Database Gateway on the Internet. Online publication. http://faostat3.fao.org/home/E
Garnsey, S. M. 1964. The nature of seasonal variation in mechanical transmission of Tulare apple mosaic virus. Doctoral dissertation, University of California-Davis.

George, J. A., and Davidson, T. R. 1963. Pollen transmission of necrotic ringspot and sour cherry yellows viruses from tree to tree. Can. J. Plant Sci. 43:276-288.

Ghanekar, A. M., and Schwenk, F. W. 1974. Seed transmission and distribution of Tobacco streak virus in six cultivars of soybeans. Phytopathology 64:112-114

Gilmer, R. M., and Way, R. D. 1963. Evidence for tree to tree transmission of source cherry yellows virus by pollen. Plant Dis. Rep. 47:1051-1053.

Greber, R. S., Klose, M. J., Teakle, D. S., and Milne, J. R. 1991. High incidence of Tobacco streak virus in tobacco and its transmission by Microcephalothrips abdominalis and pollen from Ageratum houstonianum. Plant Dis. 75:450-452.

Johnson, H. A., Jr., Converse, R. H., Amorao, A., Esperjo, J. I., and Frazier, N. W. 1984. Seed transmission of Tobacco streak virus in strawberry. Plant Dis. 68: 390-393.

Kaiser, W. J., Wyatt, S. D., and Pesho, G. R. 1982. Natural hosts and vectors of Tobacco streak virus in Eastern Washington. Phytopathology 72:1508-1512.

Klose, M. J. 1997. Transmission of Tobacco streak virus and other pollen-borne viruses by thrips. Ph.D. thesis, University of Queensland, Brisbane, Australia.

Mink, G. I. 1993. Pollen and seed-transmitted viruses and viroids. Annu. Rev. Phytopathol. 31:375-402.

Pallas, V., Aparicio, F., Herranz, M. C., Sanchez-Pina, M. A., Myrta, A., and Sanchez-Navarro, J. A. 2012. Ilarviruses of Prunus spp.: A continued concern for fruit trees. Phytopathology 102:1108-1120.

Pallas, V., Aparicio, F., Herranz, M. C., Sanchez-Navarro, J. A., and Scott, S. W 2013. The molecular biology of Ilarviruses. Adv. Virus Res. 87:139-181.

Sambrook, J., and Russell, D. W. 2001. Molecular Cloning: A Laboratory Manual, 3rd ed. Cold Spring Harbor Laboratory Press, Cold Spring Harbor, NY.

Samuel, G. 1934. The movement of Tobacco mosaic virus within the plant. Ann. Appl. Biol. 21:90-111.

Sdoodee, R., and Teakle, D. S. 1987. Transmission of Tobacco streak virus by Thrips tabaci: A new method of plant virus transmission. Plant Pathol. 36:377-380.

Sdoodee, R., and Teakle, D. S. 1988. Seed and pollen transmission of Tobacco streak virus in tomato (Lycopersicon esculentum cv. Grosse Lisse). Aust. J. Agric. Res. 39:469-474

Sdoodee, R., and Teakle, D. S. 1993. Studies on the mechanism of transmission of pollen-associated Tobacco streak ilarvirus by Thrips tabaci. Plant Pathol. 42 : $88-92$

Sharman, M., and Thomas, J. E. 2013. Genetic diversity of subgroup 1 ilarviruses from eastern Australia. Arch. Virol. 158:1637-1647.

Shimura, H., Masuta, C., Yoshida, N., Sueda, K., and Suzuki, M. 2013. The 2b protein of Asparagus virus 2 functions as an RNA silencing suppressor against systemic silencing to prove functional synteny with related cucumoviruses. Virology 442:180-188.

Webster, C. G., Frantz, G., Reitz, S. R., Funderburk, J. E., Mellinger, H. C., McAvoy, E., Turechek, W. W., Marshall, S. H., Tantiwanich, Y., McGrath, M. T., Daughtrey, M. L., and Adkins, S. 2015. Emergence of Groundnut ringspot virus and Tomato chlorotic spot virus in vegetables in Florida and the Southeastern United States. Phytopathology 105:388-398.

Zitter, T. A. 2014. Diseases caused by viruses. Pages 71-79 in: Compendium of Tomato Diseases and Pests, 2nd ed. J. B. Jones, T. A. Zitter, T. M. Momol, and S. A. Miller, eds. American Phytopathological Society, St. Paul, MN. 